MT-DP - 2016/14

\title{
Tisztesség, empátia, közgazdaságtan
}

\author{
FAZEKAS KÁROLY
}




$$
\begin{gathered}
\text { Múhelytanulmányok } \\
\text { MT-DP }-2016 / 14 \\
\text { MTA Közgazdaság- és Regionális Tudományi Kutatóközpont } \\
\text { Közgazdaság-tudományi Intézet }
\end{gathered}
$$

Tisztesség, empátia, közgazdaságtan

Szerző:

Fazekas Károly

tudományos fómunkatárs

Közgazdaság-tudományi Intézet

Magyar Tudományos Akadémia - Közgazdaság- és Regionális Tudományi Kutatóközpont e-mail: fazekas.karoly@krtk.mta.hu

2016. július

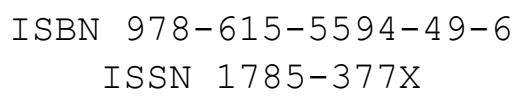

Kiadó:

Magyar Tudományos Akadémia Közgazdaság- és Regionális Tudományi Kutatóközpont Közgazdaság-tudományi Intézet 


\title{
Tisztesség, empátia, közgazdaságtan
}

\author{
Fazekas Károly
}

\section{Összefoglaló}

Mások tetteinek, cselekedeteik céljának, motivációinak megértése és megítélése az emberi társadalom és gazdaság múködésének alapfeltétele. Folyamatosan figyeljük egymás arcát, szavát, mozdulatait. Igyekszünk követni és megérteni a körülöttünk zajló eseményeket. Ennek során megpróbáljuk tapasztalatainkat interpretálni, elhelyezni az általunk már ismert és értelmezett mintázatokban. Ennek a folyamatnak három fontos eleme van: a ráhangolódás, a megértés és az értékelés. A gazdaságban az ezekhez kapcsolódó képességek a verseny és a kooperáció fontos feltételei. Az ember képessége és hajlama mások érzelmeinek, tetteinek átélésére azonban kétélü fegyver. Éppúgy ösztökél bennünket mások érdekében végzett jócselekedetekre, mint a másokkal szembeni agresszióra. De mi választja el bennünk a jót a rossztól, a segítőkész, megbocsátó embert a bosszúvágyó rombolótól, az életeket mentő filantrópot az önző fenevadtól? Képes-e ilyen kérdésekre válaszolni a társadalom és a gazdaság jelenségeinek tudományos magyarázatára hivatott közgazdasági gondolkodás? A tanulmány Adam Smith meglátásaiból von le - kérdéseink szempontjából ma is releváns - az elmúlt évtizedek tudományos eredményeinek fényében sokkal inkább megerősödő, mintsem elhalványuló tanulságokat.

Tárgyszavak: morál, gazdasági növekedés, Adam Smith, empátia, intézmények

JEL kódok: A13, B12, B31, B52, 010

A tanulmány az MTA KRTK KTI „Érték, kultúra és morál a modern gazdasági növekedés narratíváiban, c. kutatási program keretében készült. Köszönetet mondok Halpern Lászlónak, Kertesi Gábornak, Köllő Jánosnak, Mihályi Péternek, Madarász Aladárnak, Ozsvald Évának, Simonovits Andrásnak, Török Ádámnak, hogy megjegyzéseikkel, kritikai észrevételeikkel és javaslataikkal segítettek a tanulmány első változatának átdolgozásában. Az esetleges hibák és tévedések a szerzőt terhelik. 


\section{Honour, empathy and economics}

\section{Károly Fazekas}

\section{Abstract}

One of the basic premises of societies and economies is the capability of humans to understand and judge the aims and motivations of others. We are continuously observing the facial expressions of our fellows. We keep watching and try to understand the undercurrents of important events for us. While doing this, we strive for giving meaning to our experiences and try to fit them into familiar and formerly established patterns. There are three important phases of the process: empathy, understanding and judgment. Capabilities which are necessary to fulfill these tasks are important preconditions for successful competition and cooperation in the economy. Our capacity to empathize with the sentiments and deeds of the others is, however, a double-edged sword. It can induce both good-doings or harsh aggression for or against others. But, then, what is it that separates the good and the evil in humans? Lifesaving philanthropist or greedy martinet - man can be both. What is it that makes people helpful and forgiving individuals and why do they often emerge as revengeful destroyers? Can or should economic science deal with such types of inquiries? The purpose of this essay is to show that Adam Smith's insights relating to these questions provide us with thoughts which seem to be more and more relevant to contemporary scientific analysis.

Keywords: morality, economic growth, Adam Smith, empathy, institutions

JEL classification: A13, B12, B31, B52, O10 
Mért legyek én tisztességes? Kiterítenek úgyis! Mért ne legyek tisztességes! Kiterítenek úgyis.

József Attila: Két hexameter

Adam Smith, aki joggal tart igényt arra, hogy a szisztematikus közgazdaság-tudomány Ádámjának és összekovácsolójának tekintsük, a morálfilozófia professzora volt, és ez a tény volt az üllő, melyen a közgazdaságtan formát kapott.”

(Boulding [1969] 1. o.)

\section{BEVEZETÉS}

Elias L. Khalil az utánzás és az empátia messze vezető különbségeiről írt tanulmányában felidézi a BBC egyik híradását, amely szerint 2007. június 20-án, az akkor negyvenéves David Morales festő és mázoló munkából hazafelé tartva, a Texas állambeli Austin egyik parkolójában autójával elsodort egy négyéves kislányt. A baleset a Texasban évente megtartott ,júnitizedike” fesztivál ${ }^{1}$ helyszínének közelében történt, ahol a két-három ezer fős tömeg az amerikai rabszolgák felszabadítását ünnepelte (Khalil [2007]). A rendőri jelentés szerint a kocsi a baleset idején lassan haladt, így a kislány csak könnyü sérüléseket szenvedett. Amikor Morales kiszállt a kocsiból, hogy megnézze, történt-e bármi bántódása a gyereknek, egy körülbelül húsz főből álló feldühödött csoport körülvette és halálra verte.

Texas messze van, és tudjuk, empátiánk mértéke és emlékezetünk hossza fordítottan arányos a tudomásunkra jutott tragédiák tőlünk mért távolságával (Forman-Barzilai [2010], Jacobs [2015]). Abban azonban biztos vagyok, hogy az austini történet olaszliszkai változata minden magyarországi kortársam lelkébe beleégett. Néhány hónappal David Morales halála előtt, 2006. október 15-én Szögi Lajos negyvennégy éves tiszavasvári, földrajz-biológia szakos tanár, két kisebbik lányával a közeli Vámosújfaluba tartott. Olaszliszkán áthaladva, a közlekedési szabályokat betartó tanár előtt átszaladt egy kislány, és az autóval való ütközést éppen csak elkerülve, az út melletti árokba esett. Szögi Lajos megállt, hogy megnézze nem esett-e baja a gyereknek. Ekkorra odaért a kislány apja, még fiatalkorú bátyja, három további rokona, akik együttes erővel kirángatták a férfit a kocsiból és gyermekei szeme láttára agyonverték.

${ }^{1}$ https://en.wikipedia.org/wiki/Juneteenth. 
Harold Piatt, az austini rendőrség parancsnoka, így kommentálta az amerikai történetet: „Ilyen a tömeg viselkedése, ha csak egy arc vagy az ezerből. A dolgok nagyon gyorsan elszabadulnak, és az emberekben nincs elég józan belátás ahhoz, hogy lecsillapodjanak.”2 A bírósági eljárás során az olaszliszkai lincselés vádlottjai egy családjukhoz tartozó kisgyerek halálát okozó gázolás fájdalmas emléke miatt érzett fékezhetetlen felindulásukkal magyarázták szörnyü tettüket. 3

Azóta a gyilkosok itt is, ott is elnyerték büntetésüket. A rendőrség feladata, hogy felkutassa a bűnök elkövetőit, a bíróság dolga, hogy mérlegelve a törvény előírásait, az eset körülményeit, kiszabja a büntetés mértékét. Bűnt bünhődés követ. A példás retorzió azonban nem oldja fel a gyomorszorító félelmeket. Nem mondjuk ki, de érezzük: a véres indulat itt és ott csupán a háborgó felszín, amely inkább elfedi, semmint megmutatja a mélyben leselkedő veszélyeket. Nem könnyü itt higgadtnak maradni, noha a szorongó lélek, a felbolydult közhangulat rossz tanácsadó. A félelem, a düh nem tür finomkodást, fekete-fehér, könnyen érthető magyarázatot, kézenfekvő megoldásokat keres.

Pedig ez itt egy szürkezóna. Az elszabadult érzelmek, a be nem gyógyult sebek, a valódi gyötrelmek, az igazi gonoszságok, az oktalan képzelgések, a valódi és képzelt sérelmek, a megtorlások és megbocsátások kusza világa (McCullough [2008]) Ki ítéli meg, hogy eredendően hol és miért szabadultak el a dolgok? Lehet-e a tudomány feladata, hogy az ismert tényeknek megfelelő, koherens válaszokat találjon a zabolátlan indulatok mélyebb összefüggéseit firtató kérdéseinkre?

Miért van az, hogy olyan pozitív érzelmek, mint mások fájdalmának, veszteségének átélése, sok esetben nem józan és átgondolt cselekedetekhez, nem a fájdalom és a veszteség csökkentéséhez, hanem fékezhetetlen gyülölethez, bosszúvágyhoz, erőszakos cselekedetekhez vezet?

„Ilyen a tömeg viselkedése” - magyarázta Mr. Morales halálának körülményeit Piatt felügyelő. Ha csak egy vagyunk a sokból, könnyen a tömeg hatása alá kerülünk, és nem tudjuk kontrollálni saját tetteinket. Az olaszliszkai ügy másodfokú tárgyalásán a vádat képviselő ügyész arról beszélt, hogy az elkövetők „gyilkos mámorúkban” és „féktelen tobzódásukban” rugdosták halálra áldozatukat (Kácsor [2009]).

De mi késztet embereket bizonyos helyzetekben mások viselkedésének utánzására, közös üvöltözésre, masírozásra, karlendítésre, kődobálásra, gyilkos mámorra és féktelen tobzódásra? Máskor máshol mi késztet embereket mások viselkedésének megértésére, fájdalmuk vagy

2 http://news.bbc.co.uk/2/hi/americas/6224538.stm.

3 https://hu.wikipedia.org/wiki/Olaszliszkai lincsel\%C3\%Ags. 
örömük átélésére? Bizonyos időkben miért nő bennünk a harag és a gyülölet? Honnan van elementáris vágyunk a vélt vagy valós bűnösök megbélyegzésére és megbüntetésére? Honnan a bennünk készség a felejtésre, a megbocsátásra, a bizalomra és az együttmúködésre? És ne kerüljük ki a még súlyosabb, sokak szerint fel sem tehető kérdéseket. Tudható, hogy az austini lincselők feketék, az olaszliszkai gyilkosok pedig cigányok voltak. Lehet-e összefüggés az indulatok elszabadulása és az etnikai hovatartozás, az adott szubkultúra jellemzői, az iskolázottság, a szegénység, a kilátástalanság és a társadalmi kirekesztettség között?

Hatalmas irodalma van a társadalmi devianciák okait vizsgáló empirikus kutatásainak. ${ }^{4}$ A társadalomtudományok ma már képesek megmérni, szétszálazni az emberi magatartást befolyásoló hatásokat. A közgazdászok úgy vélik, hogy jó közelítéssel képesek megbecsülni az emberi magatartást befolyásoló szakpolitikai beavatkozások költségeit és hozamait, fel tudják mérni azok nem kívánt mellékhatásait (Heckman-Masterov [2007]). A válaszok után kutatva a tények gondos, elfogulatlan elemzése megkerülhetetlen. Ezúttal mégsem követjük a közgazdasági elemzések szokásos gondolatmenetét. Nem kívánjuk modellezni a csoportosan elkövetett garázdaságokkal és gyilkosságokkal kapcsolatba hozható változók összefüggéseit, és nem vizsgáljuk meg az elkövetők egyéni és társadalmi jellemzőit, a hasonló esetek gyakoriságára jellemző időbeli és területi mintázatokat.

A következő oldalakon a közgazdaságtan morálfilozófiai gyökereihez visszatérve (Boulding [1969], Young [1997]) keresünk választ a fenti kérdésekre. Nem új, hanem már régen ismert, de az elmúlt évtizedek során sok tekintetben elfelejtett vagy meg sem tanult, sokak számára már nem is tanított dolgokat szeretnénk felidézni. Csupán írást magyarázunk. Arra vállalkozunk, hogy a Deirdre McCloskey által következetesen áldottként emlegetett, sokak által a modern közgazdaságtudomány alapító atyjának tekintett, Kenneth Boulding által szellemesen a szisztematikus közgazdasági gondolkodás Ádámjának és összekovácsolójának tartott, Brad DeLong által egyenesen a közgazdaságtudomány prófétájának tisztelt morálfilozófus, pszichológus és közgazdász,5 Adam Smith meglátásaiból vonunk le nyugtalanító kérdéseink szempontjából ma is releváns, az elmúlt évtizedek tudományos eredményeinek fényében sokkal inkább megerősödő, mintsem elhalványuló tanulságokat (Boulding [1969], DeLong [2011], McCloskey [2016]).

\footnotetext{
4 A tanulmányt indító kerettörténet szempontjából különösképpen fontos Richard E. Nisbett és Dov Cohen tanulmánya az USA déli államaiban megfigyelt kiemelkedően magas gyilkossági ráta kulturális okairól. A dolgozat kiválóan ötvözi a történettudomány, a kontrollált laboratóriumi kísérletek, a terepmunkák, az elméleti pszichológia kutatási módszereit egy kényes és sokak számára provokatív területen (Nisbett és Cohen [1996]).

5 Ide kívánkozik Brad DeLong eszmefuttatása arról, miért alkalmazhatók Adam Smithre ezen a korabeli tudományos nomenklatúrában még nem használt leírások (DeLong [2011]).
} 
Joggal vetődik fel a kérdés, hogy mi szükség van erre? Hatalmas, ma is folyamatosan bővülő irodalma van az Adam Smith gondolatait interpretáló elemzéseknek. Ő nem csupán egyike a felvilágosodás iskolai tananyagba merevedett gondolkodóinak. Meglátásainak ma is érvényes gondolatairól bestsellerek jelennek meg a világban (Herman [2007], Phillipson [2010], Russ [2014]). Egy egész szellemi univerzum: egyetemek, kutatóintézetek, folyóiratok, tudományos társaságok, kutatási programok, kézikönyvek, enciklopédiák, tudományos konferenciák, blogok százai foglalkoznak kifejezetten azzal, hogy a társadalom-, a bölcsészet- és a természettudományok mai eredményeinek fényében értelmezzék megállapításait (Paganelli [2015]).

Ma már az sem igaz, hogy az olvasók nagy része Adam Smithben „csupán” A nemzetek gazdagságának szerzőjét, a láthatatlan kéz közismert metaforájának megalkotóját, az önérdek által táplált szabadpiac apostolát ismeri. Jeffrey Young már 2013-ban - némi túlzással megjegyezte, hogy Adam Smith első opusát, az Erkölcsi érzelmek elméletét többen olvassák és elemzik, mint A nemzetek gazdagságát, és általánosan elfogadott álláspont, hogy az elóbbi és nem az utóbbi jelöli ki a teljes életmú kereteit és tartóoszlopait (Young [2013]). Jól illusztrálja az érdeklődés középpontjában kibontakozó változásokat a két könyv lényegét leginkább megragadó egy-egy szó, az empátia (empathy) és az önzés (greed) előfordulási arányának változása a Google által digitalizált és feldolgozott angol nyelvú szövegekben (1. ábra).

1. ábra

\section{Az empathy és a greed szavak gyakoriságának alakulása a Google által digitalizált angol nyelvú könyvekben (1800-2008)}

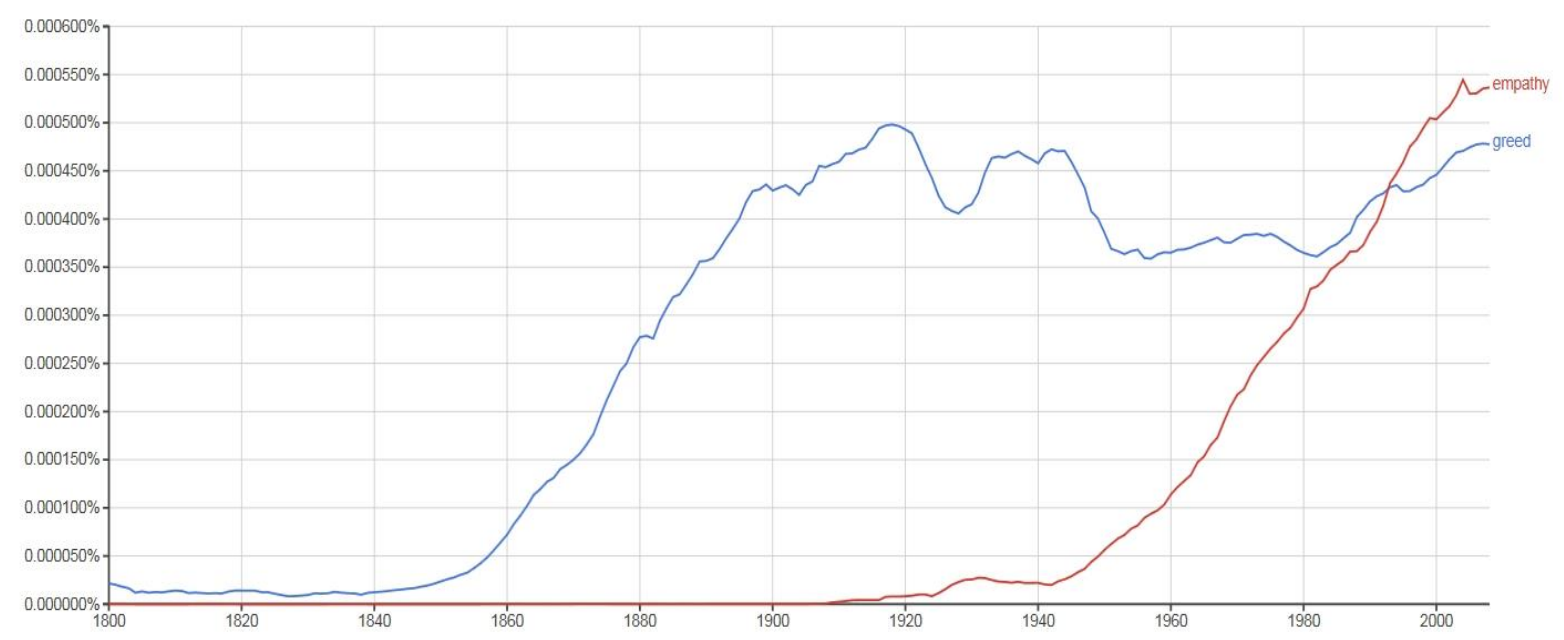

Forrás: Google Books Ngram Viewer. 
Smith morálfilozófiai és közgazdasági gondolatainak tárgyalása kapcsán még néhány éve is szinte kötelező volt utalni a két mű szemléletének valódi vagy vélt ellentmondására, az angol nyelvű szakirodalomban is németül emlegetett: „das Adam Smith Problem” feloldhatóságára vagy éppen nemlétezésére (Young [1997], Ashraf és szerzőtársai [2005]). Ma már kevesen vonják kétségbe Adam Smith morálfilozófiai és közgazdasági meglátásainak koherenciáját. (Raphael-Macfie [1976]).

Miközben e hatalmas életmű meglátásai ma is az általuk felvetett megannyi kérdés újragondolására késztet közgazdászokat, pszichológusokat, filozófusokat és természettudósokat szerte a világban, ezek az egyre gazdagabb és egyre könnyebben elérhető ismeretek Magyarországon mindinkább a könyvtárak polcaira és a szerverek memóriáiba szorulnak vissza. Miközben a mindennapokban elborít bennünket a semmire sem használható információ áradata, egész életünket meghatározó, az egyén és a társadalom számára egyaránt fontos ismeretek tekintetében a kollektív felejtés sodrása sokkal erősebb, mint a megismerésre való törekvés. ${ }^{6}$

De miért éppen Adam Smith? A közgazdászok benne diszciplínájuk alapítóját tisztelik, aki nem csupán egyik résztvevője volt a prudens gazdálkodás korabeli kérdéseiről folyó diskurzusnak. Ố volt az, aki az ipari forradalom hajnalán zseniális meglátásával elsőként adott koherens, tudományos magyarázatot arra, miként bontakozhat ki az önérdek által vezérelt egyéni döntésekből az erőforrásokat optimálisan allokáló, virágzó gazdaság. A közgazdaságtan bevezető kurzusain, mint kedvelt mantrát idézik A nemzetek gazdagságából e folyamat oly érzékletes leírását:

„Ebédünket nem a mészáros, a sörfőző vagy a pék jóakaratától várjuk, hanem attól, hogy ezek a saját érdekeiket tartják szem előtt. Nem emberiességükhöz, hanem önszeretetükhöz fordulunk, és sohasem a magunk szükségéről, hanem a rájuk váró előnyökről beszélünk nekik.”(Smith [1959] 64. o.)

Jó tudni azonban, hogy A nemzetek gazdagsága, oly sokak számára a közgazdaságtan születését megtestesítő ikonikus volta ellenére, csupán egy hatalmas szellemi vállalkozás részeként értelmezhető. Adam Smith a modern gazdasági növekedés korszakának (Kuznets [1971], Mokyr [2005]) a kezdetén egy egész életét kitöltő feladatra vállalkozott: meg akarta

6 A ritka kivételek közé tartozik a Civil Rádió Rádió-Aktivitás című műsorának a Láthatatlan kéz nyomában címmel sugárzott beszélgetése Madarász Aladárral az MTA Közgazdaságtudományi Intézetének fömunkatársával. 2013. október 11.

http://civiltudomany.blog.hu/tags/Dr. Madarász Aladár. 
ismerni az emberi cselekedetek mozgatórugóit, és ezek alapján kívánta megmagyarázni a társadalom és a gazdaság múködését, megfogalmazni a piac, a jog és a kormányzat szerepét egy prosperáló, harmonikus társadalom létrejöttében és fennmaradásában (Madarász [2008] 99. o., [2014]) Egy olyan világban, ahol nem az elszabadult indulatok, nem az ökölrázás és öldöklés, hanem a józan belátás és az együttmúködés, nem az ordibálás, hanem a gyengéd rábeszélés és ösztökélés, a „sweet talks” formálja leginkább az emberek cselekedeteit (Thaler-Sunstein [2009], McCloskey [2016]). Ha valaki, hát Adam Smith nem szolgált rá felejtésünkre és negligálásunkra. Érdemes itt idézni Jerry Evenskyt, aki 2011-ben a History of Economics Society frissen megválasztott elnökeként beiktatási beszédében a következőket mondta:

„Adam Smith 1723 és 1790 között élt. Alig több mint 200 évvel ezelőtt halt meg. 200 év egy röpke pillanat az emberi evolúció történetében. Természetünket tekintve ugyanazok vagyunk, akik voltunk 200 évvel ezelőtt. Bár az emberi képzeletnek és invenciónak köszönhetően drámaian megváltoztak a körülöttünk lévő világ összefüggései, ... az emberi képzelőerő azonban időtlen. Ez az adottság, amely megteremtette meg számunkra a 21. század technológiai csodáit, ugyanaz a képzelőerő, amely Smithnek az emberről, az emberiségről kimunkált elemzésében központi szerepet kapott. Ez ma is ugyanaz, ami akkor volt, és ez mondható el az emberi természet egészéről. Ugyanazok vagyunk, akik 200 évvel ezelőtt voltunk, és akik 200 év múlva leszünk, ugyanabból a „nyers agyagból“ megformálva, melyből Smith 1759-ben megmintázott bennünket. Mi is és a vizsgálatunk tárgya is változatlan.” (Evensky [2012] 1-20. o.)

Adam Smith gondolataival találkozni nem csupán egy messzi utazás térben és időben, sokkal inkább utazás ez saját magunkba, amelynek során - olykor meglepő és gondolatainkat felszabadító módon - tértől és időtől függetlenül saját döntéseinkről, cselekedeteink mozgatórugóiról, az egyéni boldogság és a társadalmi harmónia elérésének útjairól kapunk ma is érvényes igazságokat. Miközben Adam Smith meglátásaival foglalatoskodunk, nem csupán számunkra új ismeretekhez jutunk, de példákat kapunk arra, miként ítélhetjük meg saját cselekedeteinket mások ítéletein keresztül, miként ítélhetjük meg mások érzelmeit és cselekedeteit, mi több saját tetteinket és érzelmeinket saját empátiánk és képzeletünk segítségével. Adam Smith múveit olvasva útmutatást kapunk arra, hogy miként építhetjük fel saját magunk, lépésről lépésre, döntésről döntésre, ítéletről ítéletre, a bennünket megítélő lelkiismeretet, a lelkünkben lakozó embert. A pártatlan megfigyelőt, aki segít tisztességesnek, megbízhatónak maradni egy olyan világban, ahol egyre tágul azok köre, akik közvetlenül befolyásolják életünket, vállalkozásainkat, akiknek tisztességéről, megbízhatóságáról magunknak már nincsenek közvetlen ismereteink, és akik maguk sem tudják, hogy mi vajon megbízhatók vagy hitvány szószegók vagyunk. 
Tudjuk, „a múlt idegen ország, ott másképp zajlanak a dolgok” (Hartley [2002] 17. o.), ráadásul Adam Smith 18. századi, a müvelt brit középosztály nyelvén fogalmazott szóhasználata, elég távol áll tőlünk.7 Mégis, sokan számolnak be arról, hogy Smith olvasása során maguknak is empatikus élményben van részük. Beleéreznek a szerző gondolataiba, magukkal ragadja őket a mondatok zenéje, a példák, történetek színes hömpölygése (Klein [2013]). Russ Roberts a népszerü online közgazdasági beszélgetéssorozat, az EconTalk (http://www.econtalk.org) házigazdája így vall a Hogyan képes Adam Smith megváltoztatni az életedet? című könyvében:

\begin{abstract}
„A könyv megváltoztatta bennem azt a módot, ahogy az emberekre tekintek, és ami még fontosabb, megváltoztatta azt, ahogy magamat nézem. Smith felhívta a figyelmemet az emberek közötti olyan kapcsolatokra, amelyeket észre sem vettem korábban. A könyv időtálló tanácsokat ad arra vonatkozóan, miként bánjunk a pénzzel, vágyainkkal, a hírnév és az erkölcs kérdéseivel. Elmondja az olvasónak, hogyan lelhet a boldogságra, hogyan kezelje az anyagi sikereket és bukásokat. Felvázolja, miként lehetünk erényesek, jók és miért éri meg számunkra, hogy azok legyünk.” (Russ [2014] 4. o.)
\end{abstract}

Adam Smith könyvei kétségtelenül zavarba ejthetnek sok mai közgazdász olvasót, hiszen a szerző nem használ számokat, és nem tömöríti be gondolatait matematikai képletekbe. Nem tesz mást, mint mesél, példálózik, közmondásokat, ismert példabeszédeket idéz fel, visszautal antik gondolkodókra, korabeli francia, angol filozófusokra, regényekre, színdarabokra. Ezek a történetek azonban, nagyon is követik a glasgow-i egyetemen a fiatal Adam Smith által sok éven át tanított retorika alapszabályait. Rábeszélnek, elvarázsolnak, meggyőznek bennünket, függetlenül attól, hogy pszichológusnak, közgazdásznak, morálfilozófusnak vagy pusztán érdeklődő, gondolkodó embernek tartjuk magunkat (Boer [2014]).

\title{
ÁTÉLÉS ÉS MEGÍTÉLÉS
}

Mielőtt rátérnénk a sokak által talán már porosnak gondolt 18. századi morálfilozófiai meglátások ma is érvényes gondolataira, idézzünk fel egy levelet, amelyet 1759. július 28-án több mint 250 évvel David Morales és Szögi Lajos szörnyű halála előtt - David Hume írt patronáltjának és jó barátjának, Adam Smithnek. A levélben Hume kérdéseket tett fel és javaslatokat fogalmazott meg Az erkölcsi érzelmek elmélete második kiadásának előkészítésével kapcsolatban, és többek között a következő problémát vezette elő. Ha társaságban vagyunk, gyakori, hogy rosszkedvü, kétségbeesett társunkkal való együttérzésünk végül az egész társaság hangulatának elromlásához vezet. Ugyanakkor együttérzésünk egy gyermekét gyászoló szülővel, miközben enyhíti annak fájdalmát és szomorúságát, megkönnyebbüléssel és jóérzéssel tölt el

7 Természetesen készültek kiváló, modern angolsággal megírt Adam Smith-feldolgozások, mint például Butler [2007]. 
bennünket. Nem valószínű, hogy kétféle empátia létezik. Akkor mi az oka annak, hogy egyik esetben együttérzésünk megnyugváshoz, pozitív érzelmek átéléséhez vezet, míg más esetben az indulatok elszabadulását, negatív érzelmek eszkalációját idézi elő? Mi az, ami megfékezi bennünk az elszabaduló rosszat, felébreszti bennünk a jóságot, az együttérzést és a szeretetet és mi az, ami adott esetben felhergeli bennünk a késztetést mások és magunk rombolására?

A levél szövegéből kitűnik, és más forrásokból is tudható, hogy Hume hajlott arra, hogy az emberi természetből inkább következik az indulatok elszabadulása, eszkalációja, adott esetben a gyilkos mámor és a féktelen tobzódás, mintsem a megnyugvás és a katarzis által nyújtott öröm. Elismerte ugyan, hogy egy gyászoló vigasztalása a vigasztalóban és a megvigasztaltban egyaránt jó érzést kelthet, de némi malíciával megjegyezte, hogy ha ez lenne a jellemző eset, akkor sokkal inkább a kórházak számítanának szórakoztató intézményeknek semmint a báltermek. Ha pedig ez így van, akkor a bennünk lévő rossz, a társadalmi harmóniát romboló és oly könnyen eszkalálódó bűnös hajlamaink és cselekedeteink megfékezésének megfelelő eszköze nem lehet más, mint a kényszer: a jog iránymutatása, a helyes magatartás kikényszerítése büntetéssel és megtorlással az erre felhatalmazott erőszakszervezetek által (Mossner-Ross (szerk.) [1977] 43. o.). Adam Smith Az erkölcsi érzelmek elmélete második kiadásában végül csupán egy lábjegyzetben utalt közvetlenül Hume ellenvetésére, ám nagyon is komolyan véve kedves mentora kérdéseit, a kézirat későbbi átdolgozásai során jelentősen bővítette, finomította az empátia szerepével kapcsolatos meglátásait. Érveléséből világosan kitűnik, hogy elismerte az érzelmek és tettek elszabadulásának David Hume (és Piatt felügyelő) által felvázolt mechanizmusát, úgy vélte azonban, hogy az emberi együttérzés, a mások érzelmeire való ráhangolódás teatralitása egy másik, ennél sokkalta fontosabb, az emberi társadalom harmonikus müködését alapjaiban meghatározó folyamat kibontakozásnak is alapja. Smith meglátása szerint, éppen ennek a folyamatnak - mai szóhasználatban empátiának - a felélesztése, támogatása és kibontakoztatása, nem pedig a kényszer, nem a szabadság korlátozása, és nem is a büntetéstől való félelem fenntartása az egyéni boldogság, a társadalmi béke és a gazdasági prosperitás alapja.

Smith elismerte a Hume által jelzett szellemi fertőzés mechanizmusának létezését, de szerinte az empátia elsődlegesen nem utánzáson, hanem megértésen és megítélésen alapszik. A dolgok kimenetele ott dől el, hogy képesek vagyunk-e, akarjuk-e megérteni és megítélni a körülöttünk zajló eseményeket. Ennek a megértésnek és megítélésnek az alapja a megfigyelt és a megfigyelő érzelmeinek összehangolódása. Ez az összehangolódás akkor történik meg, ha a megfigyelő elfogadja, indokoltnak érzi a megfigyelt érzelmeinek irányát és intenzitását. A megfigyelt érzelmeinek intenzitása rendszerint nagyobb a megfigyelő érzelmeinek intenzitásánál. Ez várható is, hiszen a megfigyelő az, aki megpróbál együtt érezni a megfigyelttel. 
Ezenképpen Smith meglátása szerint a megértés folyamata a megfigyelt érzelmeinek megnyugvásához és nem az érzelmek felkorbácsolásához vezet, mivel a megfigyelt ösztönösen arra törekszik, hogy megfigyelő elfogadja az ő érzéseit, ezért csökkenteni igyekszik saját érzelmeinek intenzitását.

Smith, a korabeli kifejezést használva szimpátiának nevezte, mi a mai szóhasználathoz igazodva empátiának nevezzük az ember azon képességét és hajlamát, hogy fantáziája segítségével mások helyébe képzelje magát. Mi emberek, nem csupán értelmet kívánunk adni saját és a mások cselekedeteinek. Belső késztetésünk van arra, hogy megfigyeljük és átérezzük mások örömét és fájdalmát, mi több örömünket leljük empatikus képességünk gyakorlásában. Az erkölcsi érzelmek elméletének bevezető sorai éppoly fontos gondolatokat tartalmaznak, mint A nemzetek gazdagságának korábban idézett mantrája:

„Bármily önzőnek tételezzük is az embert, természetesen nyilvánvalóan léteznek bizonyos princípiumok, melyek mások boldogulásában őt érdekeltté, és azok boldogságát számára szükségessé teszik, noha mit sem nyer belőle, leszámítva látásának élvezetét." (Smith [1759/1977] 423. 0.)

Az empátiára való képesség és vágy az emberi faj közös öröksége. Nem más ez, mint képesség és törekvés arra, hogy átéljük és megítéljük mások érzelmeit és cselekedeteit, valamint elnyerjük a mi érzelmeinket és cselekedeteinket szemlélők és átélők elismerését. Nemcsak szeretni akarunk, de arra is vágyunk, hogy szeressenek bennünket. Mi több, többségünkben nem csupán arra vágyunk, hogy szeressenek, de azt is kívánjuk, hogy szeretetre méltók legyünk. Nemcsak sikerekre áhítozunk, de arra is vágyunk, hogy mások méltán sikeresnek ismerjenek el bennünket. Nem csupán szeretjük magunkat, nem csupán önző és élvhajhász teremtmények vagyunk, de azt is szeretnénk, hogy mások is elismerjék érzelmeink és tetteink helyénvalóságát. Önfeláldozó cselekedeteink nem egyszerúen a belénk nevelt humanitásból, jóindulatból, sokkal inkább mindannak a szeretetéből erednek, amelyet tiszteletre méltónak, nemesnek, dicsőségesnek és méltóságosnak tartunk, amit nem pillanatnyi érzéseink, hanem morális döntéseink sorozatán keresztül megszilárdult jellemünk diktál számunkra (Coase [1976]).

Smith a második kiadás után még négyszer dolgozta át, bővítette ki Az erkölcsi érzelmek elméletét. Alapvető célja az volt, hogy finomítsa, „stabilizálja”, koherenssé tegye, és tények, példák, példabeszédek, irodalmi utalások tömegével támassza alá a morális megítélésről, az empátia és a pártatlan megfigyelö, a lelkiismeret szerepéről, az önuralom és az erkölcsi tartás megerősítéséről kialakított elméletét. A terjedelmes mü végül is jórészt annak bemutatása, hogy miként képes az ember egyéni érdekeit, érzelmeit harmonizálni azokkal, akikkel élete során együtt kell múködnie (Forman-Barzilai [2010] 192. o.). 
Ahhoz, hogy Adam Smith morálfilozófiai megállapításainak társadalmi jelentőségét megértsük, tudnunk kell, hogy Az erkölcsi érzelmek elmélete szervesen kapcsolódott az európai, szúkebben a skót felvilágosodás törekvéseihez (Halteman [2003]). Annak az állításnak az alátámasztására született meg, hogy egy szekularizált, az egyházat annak világi hatalmától megfosztó világban, a társadalom morális rendjét, harmóniáját, a gazdaság prosperitását igenis lehetséges az ember érzelmeire és szabad képzeletére alapozni. Annak érdekében, hogy ebben a történelmi jelentőségű vállalkozásban valóban meggyőző érveket szolgáltasson, Adam Smithnek olyan etikai rendszert kellett megalkotnia, amely az ismert tényeknek megfelelő, koherens választ a következőkhöz hasonló kérdésekre: Miért vagyunk képesek megfelelni egy, a szabályok, kötelezettségek betartására, együttmúködésre, bizalomra épülő kereskedő - ma úgy mondanánk kapitalista - társadalom követelményeinek? Miért vagyunk alapjában véve jóakaratúak, és miért vagyunk többnyire erkölcsösek és megbízhatók, még akkor is, ha közvetlen érdekeink esetleg azt diktálják, hogy kíméletlenek, erkölcstelenek és megbízhatatlanak legyünk?

Az erkölcsi érzelmek elmélete nem a harcról és nem a versenyről, nem mások legyőzéséről szól. Azt a folyamatot írja le és magyarázza meg számtalan példával és megfigyeléssel alátámasztva, ahogy az egyén saját tapasztalataira támaszkodva megtanul önuralmat gyakorolni, megtanulja önös érdekeit, saját zsigeri érzelmeit, vonzódását vagy iszonyát, szeretetét vagy gyưlöletét, elismerését vagy rosszallását hozzáigazítani mások, általa jogosnak, helyénvalónak ítélt érdekeihez, érzéseihez, cselekedeteihez (Forman-Barzilai [2010] 192. o.).

Nem kétséges, hogy Smith mélyen egyetértett mélyen tisztelt professzorával, Francis Hutchesonnal, csakúgy, mint kedves barátjával és mentorával David Hume-mal abban, hogy az önzés, az egyéni jólét maximalizálására való törekvés az emberi magatartás immanens tartozéka. Éppen az önérdek érvényesítésének vágya az, amelyre alapozva múködnek a munkamegosztásnak és kooperációnak a családi, barátsági, vérségi kötelékeken túlnyúló területei. Ez a hajlamunk azonban még nem különböztet meg bennünket a falkában vadászó állatoktól. A sikerhez szükség van még egy, a Természet, az Isteni Gondviselés ${ }^{8}$ által belénk ültetett ösztönre, adottságra, amely lehetővé teszi, hogy egyre szövevényesebb társadalmi hálózatokban, kooperációs rendszerekben éljünk, gazdálkodjunk, iparkodjunk, kereskedjünk, kihasználjuk a gazdaság prosperitását biztosító fokozódó munkamegosztásban és technikai fejlődésben rejlő előnyöket (Henrich [2015], Wilson [2012])

8 Smith egymást felváltva - saját álláspontját homályban hagyva - használja a Természet, Isteni Gondviselés kifejezéseket, teret adva mind az evolucionista, mind a transzcendens értermezésnek. Adam Smith egész életművére jellemző ezen a területen a homályos, kétértelmü fogalmazás, ami sokkal inkább Adam Smith lelki vívódásainak, mintsem fogalmazási nehézségeinek következménye. (Coase [1976] 19. o.) 
A korábban idézett levélben David Hume első hallásra talán akadémikus akadékoskodásnak tűnő kérdése az ember érzelmi átélő képességének nagyon is veszélyes oldalára mutatott rá. Azon elementáris vágyunkra és képességünkre, hogy eggyé váljunk másokkal, hogy egyet értsünk és egyet cselekedjünk, függetlenül attól, hogy milyen cél vezeti azokat, akikhez tartozni szeretnénk, milyen meggondolások irányítják a vezért, akit követni kívánunk. Rámutatott a bennünk élő vágyra, amely arra irányul, hogy mi egy legyünk a sokból, és adott esetben átadjuk magunkat mások indulatainak, hogy összhangba kerüljünk a körülöttünk lévő tömeg érzelmeivel és mozgásával (Overy-Molnár-Szakács [2009]). Az empátia Smith felfogásában azonban nem feltétlenül jelenti azt, hogy egyetértünk és azonosulunk a másik érzelmeivel, cselekedeteivel vagy reakcióival. Nem csupán átélést, beleérzést, hanem megítélést is jelent. Megértjük, átérezzük, indokoltnak vagy indokolatlannak tartjuk azt, amit a másik érez.

Énünknek ezt az oldalát nem a racionális számítás, hanem a harmóniára való vágyakozás vezérli. Adam Smith ennek a folyamatnak az érzékeltetésére maga is gyakran használt színházi, zenei és képi kifejezéseket, hasonlatokat, metaforákat (Klein-Clark [2011]). A zene élvezete, a melódiákra, a ritmusra, a táncra való ráhangolódás hasonló ahhoz a folyamathoz, amelynek során képesek vagyunk ráhangolódni a körülöttünk lévő társadalom folyamataira, vagy éppen ellenkezőleg, felismerjük a számunka disszonáns jelenségeket, zavaró diszharmóniákat (Griswold [1999]). David Marshall hívta fel a figyelmet arra, hogy Az erkölcsi érzelmek elmélete teljes egészében a színház metaforájára épül. Ebben a narratívában a megfigyelő és a megfigyelt, a néző és a színész egymásra hangolódása, egymástól való függése az esszenciája az emberi társadalom múködésének. Empátiára való készségünk arra hajt bennünket, hogy nézőként ráhangolódjunk az általunk szemlélt ember érzelmeire. És e folyamat során a másikat, mint tükröt használva, saját érzelmeinket/cselekedeteinket is megítéljük (Marshall [1984]).

\section{TALÁLKOZÁSOK IDEGENEKKEL}

Adam Smith szerint éppen empatikus képességünk az alapja annak, hogy morális ítéleteket tudunk hozni, hogy erkölcsi tartásunk van, hogy cselekedeteinket nem pillanatnyi önérdekünk és nem az utánzás mámora, a ráhangolódás szenvedélye vezérli. Az empátia ugyanis nem puszta utánzás, hanem egy olyan érzelmi ráhangolódás, amelynek során megítéljük mások érzelmeit/cselekedeteit, és mások reakcióin keresztül megítéljük saját érzelmeinket/cselekedeteinket. Ez a megítélés a jóról és a rosszról, a helyénvalóról és az elítélendőről, az erényről és a bűnről szól. Erkölcsi döntéseket hozunk, és a döntések sorozatán keresztül kialakul, megszilárdul saját morális tartásunk, jellemünk. Az utánzás, a féktelen tobzódás és a gyilkos mámor nem más, mint megítélés nélküli empátia. 
A gond az, hogy a megítélés képessége, az önfegyelem megerősítése, a morális tartás kifejlesztése nem érhető el pusztán erős akarattal, meditációval, saját magunkkal való szembenézéssel. Ellenkezőleg, erkölcsi fejlődésünk csak társainkkal és - első hallásra talán paradox módon - leginkább az idegenekkel való találkozások, szembenézések, párbeszédek sorozatán keresztül képzelhető el (McCloskey [2016]). Smith szerint a moralitás az egyén szintjén valójában értelmezhetetlen. Erkölcsi tartásunk nem öröklött, hanem tanult tulajdonságunk, a társadalomba való beágyazódásunkból ered. Hosszú folyamat eredménye, amely születésünk pillanatától halálunkig tart. Amit örököltünk, mellyel a Természet, az Evolúció felruházott bennünket, az saját készségünk és képességünk a morális tanulás folyamatára, törekvés mások érzelmeinek átélésére, cselekedeteinek megértésére.

Felmerül tehát a kérdés, mi az alapja erkölcsi döntéseinknek, honnan a mérce, amellyel saját és mások érzelmeit, tetteit megítéljük. Adam Smith nagyon jól tudta, hogy az a szféra, amiről gondolkodott, az a való élet, ahol nincsenek angyalok és ördögök, ritkán válik el egymástól kristálytisztán a bűn és az erény. Adam Smith ráadásul, magától értetődően természetfilozófusnak tartotta magát,9 szisztematikusan törekedett arra, hogy a kor adta empirikus eszközökre támaszkodva feltárja azt a mechanizmust, amellyel az ember, erkölcsi tartásra tud szert tenni, amelynek során megtanulhatunk, dönteni jóról és gonoszról, önzésről és nagylelkűségről, hűségről és cserbenhagyásról. (Mueller [2015]).

Az életben nem csupán önérdekünk diktálta döntéseket kell hoznunk, nem kerülhetjük el, hogy újra és újra erkölcsi döntési helyzetekbe kerülünk. Ki segít rajtunk? Mibe kapaszkodhatunk? A család, a szülők, a rokonok egy ideig eligazítanak bennünket a jó és a rossz tekintetében. Kisgyermekkorunkban az óvoda, az iskola, az egyházi és baráti közösségek is közvetítik számunkra a helyi közösség és a tágabb társadalom mintáit, elvárásait. A globalizálódó kapitalista társadalomban azonban az emberek kényszerüen egyre nagyobb számban és arányban kikerülnek a helyi közösségek fészekmelegéből, egyben távolabb kerülnek azoktól a természetes „tükröktől”, amelyek megmutatják érzelmeik és tetteik elítélendő vagy elismerendő vonásait. Csupán a szabályok iránymutatásai, a dicséret, a rosszallás, adott esetekben a kényszer és a büntetés, a 19. századi skót közíró, Thomas Carlyle által, korántsem csupán átvitt értelemben, ajánlott jótékony korbács (Carlyle [1853]) ösztökélő és elrettentő ereje itt nem elegendő és nem is alkalmazható.

9 A natural philosopher a 18. századi angol nyelvben a mai természettudomány jelentésének megfelelő fogalom volt. A természet tényeken alapuló, szisztematikus tanulmányozását jelentette. 
Az erkölcsi érzelmek elmélete nem az édeni almafa ember alkotta mása, nem mondja meg az olvasónak, mi a jó és mi a rossz. A könyv arra ad útmutatást, hogy mi magunk hogyan tudunk szert tenni arra a tudásra, amellyel meg tudjuk különböztetni a jóságot a gonoszságtól. Smith morális rendszere e tekintetben hasonló a piac általa leírt múködéséhez, ahol nem csupán a jog intézményei kényszerítik ki a helyes, kívánatos viselkedést, hanem a rábeszélés, az elhallgatás, a ráhangolódás és ráhangoltatás változatos eszközei (McCloskey [2016], Young [1997]). Ez a ráhangolódás, ez a harmonizáció korántsem hangtalan és korántsem láthatatlan folyamat. Nem véletlen, hogy Adam Smith két könyvében mindössze két területen használta a láthatatlan kéz metaforáját ${ }^{10}$. Egyrészt $\mathrm{A}$ nemzetek gazdagságában az önérdek érvényesítésére épülő szabadpiac múködésének érzékeltetése, másrészt Az erkölcsi érzelmek elméletében annak érzékeltetésére, hogy az ember erkölcsi tartását kialakító önszabályozó mechanizmusok miképpen vezethetnek el harmonikus állapothoz a társadalomban. A morális ismeretek jó részének forrása nem különböző pulpitusokról elhangzó ünnepélyes prédikációkból, hanem a mindennapi élet szürke és zajos zónájában zajló látható és hallható folyamatokból ered. Éppen ez az a terület, amelyen Smith csodálatos meglátással ajándékozta meg olvasóit. Az általa kidolgozott elméletben a morális tartás kiépítésének legfontosabb eszköze nem más, mint a szabadon szárnyaló emberi képzelet.

Annak érdekében, hogy meg tudjuk ítélni saját cselekedeteink hatását másokra, képeseknek kell lennünk kívülről tekinteni magunkra. Meg kell kettőznünk saját énünket, egyszerre kell lennünk megfigyelőnek és megfigyeltnek. Mi több, képesek kell lennünk arra, hogy megfelelő távolságot hozzunk létre a bennünk lévő megfigyelő és megfigyelt között. Ezt úgy tehetjük meg, hogy másokat használunk tükörként. Mások reakcióin keresztül szemlélve magunkat, képesek vagyunk kívülról szemlélni saját cselekedeteinket. Ahhoz tehát, hogy nekünk morális tudatunk legyen, szükségünk van másokra. Morális tudat nem alakulhat ki az emberben anélkül, hogy közösségben éljen. Ha ez a kontroll hiányzik életünkből, félő, hogy ki leszünk szolgáltatva saját önszeretetünknek.

Ahhoz, hogy önérdekünkön felül tudjunk emelkedni, hogy a másik fél szempontjait is mérlegeljük döntéseink során, képesnek kell lennünk egy harmadik „semleges megfigyelőt” (impartial spectator) is bevonni erkölcsi döntéseinkbe. Egy pártatlan szemlélőt, aki saját érdekétől és a mi érdekeinktől függetlenül megítéli cselekedeteinket. Ezt a pártatlan megfigyelőt, Adam Smith meglátása szerint, saját képzeletünk teremti meg számunkra egy tanulási folyamatban, amelynek során újra és újra döntési helyzetekbe kell kerülnünk, újra és újra bele

${ }^{10}$ Alec Macfie hivta fel a figyelmet arra, hogy Smith először egy ifjúkori csillagászattörténeti esszéjében használta a láthatatlan kéz metaforáját annak érzékeltetésére, hogy miképpen különbözik a valóság racionális és transzcendens magyarázata. (Madarász [2014]. 823.0.) 
kell néznünk e virtuális pártatlan megfigyelő szemébe, míg megerősödik saját morális karakterünk.

Mi segít, és mi gátol bennünket ebben a fejlődésben? A morális fejlődésre való képesség öröklött tulajdonságunk, amelyet kisgyermekkorban a család, a közvetlen környezet képes fejleszteni, gazdagítani bennünk. Ahhoz azonban, hogy morális értelemben felnőtté váljunk, ki kell lépni a család, a helyi közösség zárt világából, világot kell látni, kapcsolatba kell kerülni az idegenekkel, más szokások, más kultúrák, más értékek képviselőivel. ${ }^{11}$ Hiszen az egyén és az emberi közösségek felvirágzásának alapja éppen az idegenekkel való együttmúködésre való képességünk. Minél távolabbra kerülünk a családi, rokonsági, törzsi, baráti kötelékektől, annál nagyobb szerepe van az emberi kapcsolatokban az egyéni érdekeknek, de ezzel párhuzamosan, annál nagyobb szerepe van a kooperációs képességnek, annak hogy képesek vagyunk mások érdekeit és értékeit számításba venni.

Ezen az úton idő és kitartás kell a sikerhez. Szükség van bölcsőkre, olyan terekre, ahol kialakulhat az egyének morális karaktere. Ezek a bölcsők nem lehetnek túl szűkek, mert akkor nem adnak lehetőséget arra, hogy kialakuljon bennünk az eltérő érdekek, értékek, kultúrák figyelembevételének képessége. ${ }^{12}$ Nem lehetnek túl tágak, mert túl távoli tükörben nem látjuk meg saját torzulásainkat vagy éppen fejlődésünket. Egyenessé oly módon válhatunk, úgy tanuljuk meg az önfegyelmet, úgy szerezhetünk erkölcsi tartást, hogy a helyzeteket, amelyekben döntenünk, cselekednünk kell, megfelelő távolságból szemléljük: szembesülve tetteink következményeivel, újra és újra gyakoroljuk, miképpen tudunk parancsolni különböző kihívásokkal szembe nézve indulatainknak, miképpen tudunk túllépni pillanatnyi érdekeinken.

Az egyén és a társadalom morális tartásának, morális rendjének fejlődése azonban nem pusztán erkölcsi üzenetek továbbításának, nem az ige fennen való hirdetésének és nem is gondos társadalmi tervezési folyamat megvalósításának eredménye, hanem a kereskedelem és a munkamegosztás fejlődésének nem szándékolt, de elkerülhetetlen következménye.

Ugyanakkor a cselekedeteinket és érzelmeinket elbíráló, „lelkünkben lakozó ember” pártatlansága is lehet zárt, korlátozott, parókiális. Ha nem tudunk rendszeresen kilépni szúkebb közösségünkből, etnikai, nemzeti csoportjainkból, tanácstalanok leszünk, ha ki kell lépnünk

${ }^{11}$ Érdemes felidézni, hogy miképpen fogalmazta meg ezt a gondolatot gróf Forgách Mihály kétszáz évvel korábban a Wittenbergi Magyar Társaság ülésén, az utazás dicsőségéről szóló székfoglaló beszédében: „És, könyörgök, esztelenség az, hogy a hazának üdvére szolgálhatsz és előmenetelére lehetsz, amikor nem szerzed meg idegen tájakon a tudomány kellékeit, az erény és bölcsesség eszközeit, esztelenség az, hogy égsz a szülők iránti szeretettől, nekik a dicsőségben díszükre, a veszedelemben segítségükre, a szenvedésben vigaszukra válsz, amikor inkább bámulod állandóan az ő müveletlen és tudatlan arcukat, ábrázatukat, és nem távozol inkább egy időre messzebbre a szemük elől...” (Forgács [1587]

12 Lásd például Robert Putman klasszikus tanulmányát a zárt családi közösségek moráljáról (Putman [1992]). 
saját megszokott közegünkből. Amartya Sen nyílt pártatlanságnak nevezi azt a képességet, amelyre az ember morális iránytűje nemzeti, etnikai kereteken túllépő kapcsolatain, tapasztalatain, morális döntésein keresztül tesz szert (Sen [2009] 60. o.). A család, a közeli barátok tehát bármennyire fontosak is számunkra, túl közel állnak hozzánk ahhoz, hogy elegendők legyenek erkölcsi tartásunk, önuralmunk megerősödéséhez. A kisgyermeknek nincs öröklött képessége az önuralomra. Ezért is tulajdonít Adam Smith oly kiemelkedő jelentőséget a koragyermekkori oktatásnak (Paganelli [2010]). Az óvoda, az iskola nem csupán ismereteket nyújt a gyermekeknek, hanem fontos lehetőséget teremt arra, hogy a gyermekek folyamatosan szembesüljenek őket kívülről szemlélő „idegenek” megítélésével. Az iskolából az életbe kilépve sincs ez másképp. Folyamatosan gyakoroljuk a megfigyelő szerepét, és minél tapasztaltabbak vagyunk, annál inkább képesek vagyunk megítélni mások cselekedeteit, érzelmeit. Morális fejlődésünk, akár a munkához szükséges ismeretek elsajátítása, egész életünkön át tartó folyamat.

A távolságnak több dimenziója van, a földrajzi közelség mellett a társadalmi távolságok, a kulturális különbségek is befolyásolják, mennyire vagyunk képesek visszacsatolásokat befogadni saját morális döntéseink következményeiről. A modern társadalomban éppen a piac, a kereskedelem, a társadalmi élet hazai és nemzetközi szinterein kaphatunk folyamatos visszacsatolást saját magunk és saját közösségünk morális döntéseiről. A nemzetek gazdagsága annak kifejtése, miként járul hozzá a munkamegosztás és a kereskedelem a jólét növekedéséhez. Éppen a távolság legyőzése, az idegenekkel való gyümölcsöző kapcsolatok fenntartása integrálja A nemzetek gazdagságának elméleti megközelítését $\mathrm{Az}$ erkölcsi érzelmek elméletének argumentációjába. Ekképpen mindkét mü a liberális kapitalista társadalom mellett érvel, hiszen épp a kereskedő társadalom biztosítja, hogy az egyén saját morális fejlődését elősegítő megfelelő közelségben és távolságban legyen a társadalom más tagjaitól.

A kereskedő társadalmaknak épp az a jellemzőjük, hogy idegenek együttmúködésére épülnek. Smith fontos meglátása, hogy a társadalom tagjainak gyakori és stabil kitettsége az idegeneknek, ösztönzi a társadalom tagjainak morális fejlődését. ${ }^{13}$ Smith ezen a pontos is szakít korának közkeletű nézetével, amely szerint a kereskedés, a kapitalista gazdaság térhódítása önzővé, pénzsóvárrá teszi az embereket, és maga is hozzájárul az erkölcsi hanyatláshoz és a kooperációs készség csökkenéséhez (McCloskey [2016], Zak [2008]).

${ }^{13}$ Különösképpen figyelemre méltó e tekintetben Weiner [2016a], [2016b] elemzése arról, miért voltak a zseniális intellektuális teljesítményt nyújtó emberek között kiugróan arányban azok, akik emigrációban érték el kiemelkedő teljesítményeiket. 


\section{A MỨVÉSZETEK ÉS A RETORIKA SZEREPE}

Adam Smith halála előtt egy héttel intézkedett arról, hogy a végrendelet végrehajtására felkért barátai halála után égessék el még nem publikált jegyzeteit és kéziratait. A barátok kitartó kérlelése ellenére csupán néhány, általa publikálásra késznek tekintett kézirat megtartását engedélyezte, a megsemmisítésre ítélt oldalak elégetését maga ellenőrizte. A megmaradt szövegek között volt két olyan esszé (Smith [1983]), amelyek jól mutatják a szerző zseniális képességét az egymástól távoli dolgok közötti összefüggések meglátására.

Ilyen például annak bemutatása, hogy milyen szerepet játszanak a müvészetek erkölcsi fejlődésünkben, a társadalom és a gazdaság harmonikus múködésében és fejlődésében. Adam Smith szerint morális tartásunk fejlődése lényegében morális érzékenységünk kitágítása - ma úgy mondanánk: morális intelligenciánk fejlesztése (Wight [2006]) A művészeti alkotások élvezete olyan érzelmi kapcsolódásokat hoz létre bennünk, amelyek segítenek empátiánk térbeli és társadalmi kiterjesztésében. Így az irodalom, a színház élvezete lehetőséget ad számunkra, hogy képzeletünk segítségével olyan érzelmeket, a szenvedélyek olyan árnyalatait éljünk át, amelyekkel életünk során a valóságban nem találkozhatunk. Azáltal, hogy egy irodalmi, színházi, képzőművészeti alkotás olvasása, megtekintése, szemlélése során a pártatlan megfigyelő szerepébe helyezhetjük magunkat, anélkül kapunk lehetőséget erkölcsi ítéletek meghozatalára, hogy tévedéseink következményeit nekünk vagy másoknak viselni kellene (Sund [2010]). Morális fejlődésünk tehát nem a mai értelemben vett tanulás vagy tudományos megismerés, hanem sokkal inkább próbák és hibák sorozatának eredménye. Ha metaforába szeretnénk süríteni e folyamat lényegét, az sokkal inkább kibontakozás, semmint megvilágosodás.

Korábban már említettük, hogy Az erkölcsi érzelmek elméletének egész argumentációjában, az általa használt metaforákban és történetekben fontos szerepe van a színháznak (Marshall [1984]), a közönség és a színész viszonyának. A színház itt nem csupán kerettörténet, hanem az emberi élet egészének metaforája. A színészi játék kellékei: a gesztikuláció, az arc és testbeszéd jelentései mindannyiunk számára érthető, kortól és tértől független, az evolúció által belénk égetett attribútumai az emberi fajnak. A csapongó képzelet, amelyet nem kötnek gúzsba a helyekhez és időkhöz, kultúrákhoz kötődő adottságok, sokkal inkább közelebb hoz, semmint szétszakít bennünket. Az emberi képzelet képes áthidalni a teret, az időt, a kulturális különbségeket. Smith a múvészetek erkölcsi fejlődésünkre gyakorolt hatása kapcsán többször is hangsúlyozza a múvészeti élmény érzelmeinkre gyakorolt sokkoló hatását. Az irodalomban az általunk megismert hősök kalandjai, tragédiái felélénkítik érzelmeinket, felébresztik és tettre késszé teszik a bennünk lakozó pártatlan megfigyelőt. A múvészetek akkor képesek leginkább 
erre a feladatra, ha stimulálják képzelőerőnket, ha nem tökéletes másolatai a valóságnak, hanem tökéletlenségükben, aránytalanságukban, absztrakcióikban teret adnak képzelőerőnknek. Ha lehetővé teszik számunkra a velük való „párbeszédet”.

A múvészetek korántsem a puszta élvezetek forrásai. Képesek hatékony eszközéül szolgálni az emberi társadalom alapját jelentő meggyőzési mechanizmusoknak. A retorika a szavak múvészete, a gondolat finom árnyalatainak megjelenítője, az érzelmi hullámzások hű kifejezésének eszköze. Egy piaci társadalomban az élet nem más, mint a retorika múvészetének folyamatos gyakorlása. Smith meglátása szerint különösképpen hátrányos helyzetben vannak azok, akik kikerülnek ebből a diskurzusból, akik nem tudják vagy nem akarják kitágítani, rugalmasabbá tenni mentális modelljeiket, többek között az irodalom, a zene, a színház és más müvészetek élvezete és gyakorlása által.

A szavak, a múvészeti alkotások azonban nem csupán a megértés, sokkal inkább a rábeszélés eszközei. Kenneth Boulding már 1968-ban az Amerikai Közgazdasági Társaság 81. ülésén A közgazdaságtan mint morális tudomány címmel tartott elnöki beszédében Adam Smith morálfilozófiájából kiindulva a morális rendszerek evolúciós ökológiájáról beszélt (Boulding [1969]). A sikeres etikai rendszerek olyan szubkultúrákat alakítanak ki, amelyek maguk is terjesztői az őket létrehozó értékrendszereknek. Ezek a rendszerek sokkal gyorsabb átalakulásra, terjedésre és összeomlásra képesek, mint a biológiai ökológiai rendszerek.

\section{A RENDSZER EMBERE}

A kereskedő társadalom harmonikus fejlődésének erkölcsi alapjairól Smith által felrajzolt kép sokunk számára túlságosan is naivnak, utópisztikusnak tünhet. Mindannyian tudjuk, hogy a valóságban az egyéni sorsok és a társadalmi folyamatok eredménye gyakran nem a harmónia, és a boldogság, hanem ellenkezóleg a nyugtalanság, a fájdalom, az igazságtalanságok és kegyetlenkedések eluralkodása. Adam Smith, különösen utolsó éveiben, igyekezett szembenézni e ténnyel, és nem csupán magyarázatokat keresett, de megpróbált megoldásokat is találni a már az ipari forradalom hajnalán is fenyegetően sokasodó társadalmi problémákra. Ami a bajok okait illeti, ezúttal csupán két olyan gondolatot emelünk ki, amelyek az empátia torzulásaira, illetve az empátia hiányára vonatkoznak. Az első a mások imádata, saját tehetetlenségünk, alávetettségünk átélése és elfogadása, a második az önimádat és arrogancia eluralkodása.

Adam Smith szerint az empátiának két eltérő formája létezik. A kölcsönös szimpátia (mutual sympathy) az embernek a szeretetreméltóság, társadalmi beágyazottság és egyszerűen a társaság iránti eredendő vágyából ered. A kölcsönös szimpátia kialakulása feltételezi a felek érzelmeinek egymásra hangolódását. Itt tehát egy szimmetrikus összehangolódásról van szó, 
amelynek során a felek anélkül érzik át kölcsönösen az együttérzés által kínált örömöket, hogy ítéletet kellene mondaniuk a folyamatba bevont érzelmekről. Smith különleges szimpátiának (peculiar sympathy) nevezi azt az érzelmet, amely társadalmi rangokhoz, politikai irányultságokhoz kapcsolódik. Ennek kialakulása az ember azon természetes vágyához kapcsolódik, hogy sikeres, egyedi, valamiben kiemelkedő legyen. A világ azonban nem kedvez a tömegeknek, így a sikerre és kiválóságra csak kevesen képesek. Ennek a fenyegető helyzetnek a tudata, az ebből fakadó csalódottság elkerülése hajt bennünket arra, hogy igyekezzünk átélni a sikeresek, a hatalmasok, a kiválók örömét, és együtt lelkesedjünk, örüljünk az őket éltető tömeggel. Ez a jelenség vezet a gazdagok és a hatalmasok, a sztárok csodálatához, de Smith szerint ugyanez az érzés segíti elő a társadalmi harmóniát és ez az alapja az állam, illetve minden politikai entitás iránti elkötelezettségnek, hűségnek és önfeláldozásnak. És éppen itt erednek azok a folyamatok is, amelyek éppen ezt a harmóniát és fejlődést veszélyeztetik, és könnyen a morális, társadalmi, gazdasági rendszer összeomlásához is vezethetnek.

A Smith által különös jelzővel illetett empátia nem pusztán mások csodálatára, saját alávetettségünk, sikertelenségünk átélésére késztethet bennünket. Nagy a kísértés arra, hogy saját kezünkbe vegyük az események irányítását annak érdekében, hogy mi magunk, és ne mások határozzák meg a folyamatok kimenetelét. Adam Smith csak halála előtt hetekkel készült el Az erkölcsi érzelmek elmélete hatodik, átdolgozott kiadásával, amelybe beleillesztett egy nagyon fontos, a jelenkorból visszatekintve látnoki erejú gondolatsort arról az - általa „rendszer emberének" nevezett - embertípusról, aki hajlama, neveltetése, tapasztalata miatt enged ennek a kísértésnek. A rendszer embere oly mértékben képes „beleszeretni” saját céljaiba és a világ múködéséről vallott elképzelésébe, hogy habozás nélkül kész ráerőltetni saját akaratát másokra anélkül, hogy azon tépelődne, vajon saját preferenciái megegyeznek e mások elképzeléseivel. Ő az arrogancia és a mértéktelen önimádat embere, aki képesnek érzi magát arra, hogy a társadalom tagjait, mint bábukat a sakktáblán ide-oda tologassa saját mesterterve szerint.

Csakhogy - hívja fel figyelmünket Adam Smith a nyilvánvalóra - a sakkbábukkal szemben az emberi társadalom nagy sakkjátszmáiban minden egyes embernek saját akarata, saját mozgása van, amelyet a rendszer embere az intézmények fabrikálásában és a törvények gyártásában szorgalmatos törvényhozás segítségével sem tud kénye-kedve szerint befolyásolni. Ennek az amúgy nyilvánvaló ténynek a figyelembe nem vétele előbb-utóbb a társadalom széteséséhez, a rendetlenség eluralkodásához, az érzelmek szabályozhatatlan eszkalációjához, erőszakhoz és tragédiákhoz vezet. 
Mi az, ami mégis egyben tartja azokat a társadalmakat, amelyeket a rendszer emberei irányítanak? Mi az, ami vonzóbb és kívánatosabb, mint az Adam Smith által olyannyira csodált szabadság, harmónia és kiegyensúlyozottság? És mi az, ami jóval veszélyesebb, mint az érzéketlen sakkozó által felhergelt közhangulat? A közgazdászok hajlamosak arra, hogy ne értsék meg mindazokat a veszélyeket, amelyeket a rendszer embere testesít meg Adam Smith morálfilozófiájában. Hiszen a közgazdasági gondolkodás nehezen képes kezelni a jóakaratot és a rosszakaratot. A költségek és hasznok elemzése nem magyarázza meg jóságból, vagy ellenkezőleg, gonoszságból eredő döntéseinket. Mivel mindannyian valamiféle morális tartással rendelkező emberek vagyunk, döntéseinket nem csupán önérdekünk, hanem saját identitásunk, értékeink is befolyásolják. És éppen ez a mások által való befolyásolhatóság teszi lehetővé, hogy bizonyos helyzetekben megcsaljon bennünket saját lelkiismeretünk.

Kenneth Boulding a közgazdaságtan erkölcsi alapjairól írt esszéjében hősi etikának nevezi, amikor jó s rossz közötti választásunk nem megélt tapasztalatainkon, nem tetteink várható következményein, hanem belénk égetett szimbólumokhoz, megkérdőjelezhetetlen hitelvekhez kapcsolódó rutinokhoz, katonai, vallási rituálékhoz vagy éppen a sportban elérhető dicsőséghez kapcsolódnak (Boulding [1969]). Nem kétséges, hogy a történelem csillagóráiban hatalmas ereje van a hősi elkötelezettségeknek. Nincs skót felvilágosodás, nincs se Francis Hutcheson, se David Hume, se Adam Smith, ha nincs a református John Knox, aki saját megingathatatlan hitével és megkérdőjelezhetetlen autoritásával, drákói rendeleteivel, kegyetlen büntetéseivel megteremtette a Kirk-et, a független skót presbiteriánus egyházat, amely minden bigottsága ellenére a megfelelő időben szellemi talajt és cselekvési lehetőséget adott a skót felvilágosodás számos megtestesítőjének (Herman [2007]). És nem lett volna Kálvin és kálvinizmus, ha nincs Luther Márton, aki kiáll 1520-ban a wormsi birodalmi gyúlés elé és elmondja: „Itt állok, másként nem tehetek.” Hogy is lenne helye ott közgazdasági megfontolásoknak, ahol a hit, a haza, a becsület és a dicsőség dolgai jelentik a tétet. Nem kétséges, hatalmas erőt jelenthet számunkra a hősi morál. Önfeláldozásra, saját érdekeinkről való megfeledkezésre késztethet bennünket, olyan szimbolikus alkotások létrehozására mozgósíthat, mint a fenséges középkori katedrálisok vagy a rajongás jelenkori rituáléinak és az önkívületnek teret adó arénák és futballstadionok.

A csillagórák után jönnek a szürke hétköznapok. Mit teszünk, ha nem találjuk a helyünket a piacgazdaság szürke és piszkos mindennapjaiban? A nagygyúléseknek, istentiszteleteknek, futballmeccseknek egyszer vége van, és az emberek hazatérnek dolgaikat intézni. A mindennapokban derül ki, valóban müködőképes-e és sikeres-e a rendszer. Pusztán a szükségesnek tartott intézmények megléte még nem jelenti azok hatékony múködését. A legitimitást, a múködőképességet, a hatékonyságot a társadalmi ökoszisztéma egésze adja meg, 
és ebben döntő jelentősége van a kommunikációnak, a rábeszélésnek, McCloskey szavaival az édes beszédnek. Adam Smith újra és újra arra figyelmeztet bennünket, hogy a dolgok jobbra fordítása nem a csatamezőn dől el, nem mások legyőzésén, nem saját akaratunk másokra erőltetésén múlik, hanem a szabad emberek gyülekezetének egymással való folyamatos párbeszédén.

\section{EPILÓGUS}

Adam Smith életmüve számtalan olyan zseniális meglátást tartalmaz, amelynek finom mintázatait, fiziológiai alapjait, fenntartó mechanizmusait a tudomány mai fejlettségén már képesek vagyunk legalább részben magyarázni, és tudományos igényel verifikálni. Egy több mint 200 évvel ezelőtt élt tudós természetesen mit sem tudhatott az általa felvázolt pszichológiai folyamatok fiziológiai alapjairól. Megállapításainak forrása az általa feldolgozott irodalom, saját és mások érzelmeinek, cselekedeteinek szisztematikus rögzítése volt. A 18. század számos morálfilozófiai kérdésére csupán az elmúlt években kaphatunk természettudományos, a jelenségek fiziológiai mechanizmusait feltáró válaszokat.

A közgazdaság-tudomány számos területe, amikor az emberi magatartás valóságos jellemzőit próbálja beépíteni az általa használt elméleti keretekbe, megkerülhetetlenül szembesül, párbeszédre kényszerül Adam Smith meglátásaival. Így lesz Adam Smith előfutára a modern magatartási közgazdaságtannak, az evolúciós közgazdaságtannak, a neuro-közgazdaságtannak, az intézményi közgazdaságtannak, a retorikai közgazdaságtannak. Adam Smith meglátásai nem csupán a Kahneman és Tversky [1979]) által leírt veszteségkerülés fogalmában, a jövőbeli veszteségek és nyereségek jelenértékének kezelésében, a nyereségek és veszteségek valószínúségének torzításaiban, az altruizmusra, az igazságosságra való hajlam, a közjavakra vonatkozó közösségi döntések motivációinak megértésében segítik a mai közgazdászokat. A kísérleti közgazdaságtan, a kísérleti antropológia, a kísérleti pszichológia nem csupán igazolják Adam Smith meglátásait, de sok területen éppen Smith meglátásai ösztönöznek bennünket új kérdések felvetésére. Az empátia fogalmával kapcsolatban talán a legfontosabb kérdés: az a képességünk, hogy átérezzük, megértsük és értékeljük mások fájdalmát és örömét, cselekedeteinek mozgatórugóit, mennyiben a biológiai evolúció során belénk rögzült, velünk született képesség, és mennyiben tanulható, tanítható, fejleszthető készség? A kérdéssel foglalkozó magatartástudományi és neurológiai kutatások azt támasztják alá, hogy már kisgyermekkorban készek és képesek vagyunk empatikus megértésre és értékelésre (Hamlin és szerzőtársai [2007]). Ezért különösképpen fontos gondolatot jelent számunkra Adam Smith meglátása a kisgyermekkori fejlesztés fontosságáról, az eltérő szempontokat közvetítő iskolai 
közösségek szerepéről az empatikus képesség fejlesztésében, az önfegyelem képességének megszilárdulásában, az erkölcsi tartás kialakulásában. ${ }^{14}$

Adam Smith legfontosabb meglátása kétségkívül a kapitalista piacgazdaság, Deirdre McCloskey - korántsem elfogulatlan - megfogalmazásával a piac által tesztelt fejlődés (Market Tested Betterment) és az egyén morális fejlódésének összefüggéséhez kapcsolódik. A szabad vállalkozás sikeressége nem csupán megköveteli, hogy megbízhatóak és bizalomra képesek legyünk, a piacgazdaság müködése maga is hozzájárul morális fejlődésünkhöz. Az austini és olaszliszkai ártatlan áldozatok és a felbőszült gyilkosok, a kiszolgáltatott jók és a megfékezhetetlen rosszak életét alapvetően nem az állami erőszak és nem is az állami gondoskodás mentheti meg, teheti elviselhetővé, boldoggá, tisztességessé és törvénytisztelővé, hanem a szabadpiaci kapcsolatok lényegét jelentő, párbeszédekből, rábeszélésből, megállapodásokból kibontakozó, napról napra, generációról generációra megerősödő bizalom és kooperáció. (Pinker [2011]) Áldottak azok, akik szavaikkal és tetteikkel felébresztik, megerősítik lelkiismeretünket, morális tartásunkat ebben a folyamatban és kárhozottak azok, akik kisajátítják a döntést jó és rossz között, akik dogmákba, a félelem és a kiszolgáltatottság bugyraiba gyömöszölik azokat, akik életre, szabadságra és boldogságra születtek.

14 John Rae, Adam Smith 19. századi életrajzírója megemlít egy különös epizódot a főszereplő gyerekkorából. „Négyéves korában, amikor [Adam Smith] meglátogatta nagyapja strathendry-i házát, a leveni rakparton sétáló gyereket egy, a területen áthaladó cigánykaravánhoz tartozó nő elrabolta, ... A keresők ... a leslie-i erdőben meg is találták a cigánykaravánt. Az asszony meglátva a közeledő embereket, a gyereket hátrahagyva elmenekült. A kisfiút ezután visszavitték édesanyjához. ... Ezt követően folyamatosan javult a gyerek egészsége, és végül anyja a megfelelő korban Kircklady legjobb iskolájának számító Burgh Schoolba iratta be.” Rae csupán egy rövid megjegyzést füzött még a történethez: „Attól félek, Adam Smith igen közel volt ahhoz, hogy egész életében egy szegény cigányember legyen" (Rae [1895] 22. o.). 


\section{HIVATKOZÁSOK}

Ashraf, N.-Camerer, C. F.-Loewenstein, G. (2005]: Adam Smith, Behavioral Economist. Journal of Economic Perspectives, Vol. 19. No. 3. 131-145. o.

Boer, R. [2014]: Adam Smith, Storyteller. Political Theology Today, január 22. http://www.politicaltheology.com/blog/adam-smith-storyteller.

Boulding, K. [1969]: Economics as a Moral Science. The American Economic Review, Vol. 59. No. 1. 1-12. o. http://dx.doi.org/10.1257/aer.101.3.166.

Butler, E. [2007]: Adam Smith - a Primer. The Institute of Economic Affairs, London. http://www.iea.org.uk/sites/default/files/publications/files/upldbook414pdf.pdf.

CARLYLE, T. [1853]: The Nigger Question. Megjelent: The Collected works of Thomas Carlyle. Vol. XIII. Latter-Day Pamphlets. Chapman and Hall, London, https://books.google.hu/books/reader?id=2pYMAAAAYAAJ\&printsec=frontcover\&output $=$ reader\&source $=$ gbs atb hover\&pg $=$ GBS.PP7.

CoAse, R. H. [1976]:_Adam Smith's View of Man, Journal of Law and Economics, Vol. 19, No. 3, 1776: The Revolution in Social Thought (Oct., 1976), pp. 529-546

DeLong, B. [2011]: Is Adam Smith Partly an Economist, or Wholly a Moral Philosopher? Grasping Reality with All Tentacles. március 25. http://delong.typepad.com/sdj/2011/o3/is-adam-smith-partly-an-economist-or-wholly-amoral-philosopher.html.

Evensky, J. M. [2012]: What's Wrong with Economics? The Journal of the History of $\begin{array}{lllllll}\text { Economic Thought, } & \text { Vol. } & 34 . & \text { No. } & 1 . & 1-20 . & 0 .\end{array}$ http://dx.doi.org/10.1017/s1053837212000028.

FORGÁCH, M. [1587]: Beszéd az utazásról és dicsőségéről. Wittenberg, Zacharias Crato nyomdája, $\quad 1587 . \quad$ (Fordította: $\quad$ Kulcsár http://www.mek.oszk.hu/06100/06179/html/magyutaz0010010001/magyutazo0100100 01.html

Forman-BARZILAI, F. [2010]: Adam Smith and the Circles of Sympathy. Cosmopolitanism and Moral Theory. Cambridge University Press, Cambridge, 3140.

GRISWOLD, C. L. JR [2006]: Imagination: Morals, Science, and Arts. Megjelent: Haakonssen, $K$. (szerk.): The Cambridge Companion to Adam Smith. Cambridge University Press, Cambridge, 22-56. o.

GRISwOLD, C. L. JR. [1999]: Adam Smith and the Virtues of Enlightenment. Cambridge University Press, Cambridge, U. K.

Halteman, J. [2003]: Is Adam Smith's Moral Philosophy an Adequate Foundation for the Market Economy? Journal of Markets \& Morality, Vol. 6. No. 2. 453-478. o. http://www.marketsandmorality.com/index.php/mandm/article/viewFile/458/448

HAMLIN, J. K. és szerzőtársai [2007]:_Social evaluation by preverbal infants, Nature 450, 557-559 (22 November 2007) | doi:10.1038/natureo6288

HARTLEY, L. P. [2002]: The Go - Between. New York Review of Books, New York.

Heckman, J. J.-MASTERov, D. V. [2007]:_The Productivity Argument for Investing in Young Children_T.W. Schultz Award Lecture at the Allied Social Sciences Association annual meeting, Chicago, January 5-7, 2007. http://jenni.uchicago.edu/Invest/ 
HenRICH, J. [2015]: The Secret of Our Success: How Culture Is Driving Human Evolution, Domesticating our Species, and Making us Smarter. Princeton University Press, 318. o.

Herman, A. [2007]: How the Scots Invented the Modern World. The True Story of How Western Europe's Poorest Nation Created Our World and Everything in it. Crown/Archetype. 480. o.

JACOBS, F. [2016]: The Geography of Empathy and Apathy. Big Think, november 17. http://bigthink.com/strange-maps/the-geography-of-empathy-and-apathy?

KÁCSOR ZSOLT [2009]: Az olaszliszkaiak lincselését egyszer már megakadályozta a rendőrség, Népszabadság. október 30.

Kahneman, D.-Tversky, A. [1979]: Prospect Theory: An Analysis of Decision under Risk. Econometrica, Vol. 47. No. 2. 263-291. o. http://dx.doi.org/10.2307/1914185.

KHALIL, E. L. [2007]: The Mirror-Neuron Paradox: How Far is Sympathy from Compassion, Indulgence, and Adulation? MPRA Paper, No. 3961. https://mpra.ub.unimuenchen.de/3961/1/MPRA paper 3961.pdf.

KHALIL, E. L. [2011]: The mirror neuron paradox: How far is understanding from mimicking? Journal of Economic Behavior and Organization, Vol. 77. No. 1. 86-96. o. http://dx.doi.org/10.1016/j.jebo.2009.12.005.

KLEIN, D. B. [2013]: Come together in Adam Smith. OUPblog, Oxford University Press, október 23. http://blog.oup.com/2013/10/come-together-in-adam-smith.

KLEIN, D. B.-ClaRK, M. J. [2011]: The Music of Social Intercourse Synchrony in Adam Smith. The Independent Review, Vol.15. No. $3 . \quad 413-420 . \quad 0$. http://dx.doi.org/10.2139/ssrn.1589133.

KuZneTS, S. [1971]: Modern Economic Growth: Findings and Reflections. Lecture to the memory of Alfred $\quad$ Nobel, 11. http://www.nobelprize.org/nobel_prizes/economic-sciences/laureates/1971/kuznetslecture.html.

MADARÁSZ ALADÁR [2008]: Visszatérhet-e a „nagy elmélet” a közgazdaságtanban? Megjegyzések a rendszerparadigma elmélettörténetéhez. Közgazdasági Szemle, 55. évf. 2. Sz. 95-106. o.

MADARÁSZ ALADÁR [2014]: A láthatatlan kéz - szemelvények egy metafora történetéből, Közgazdasági Szemle, LXI. évf., 2014. július-augusztus (801-844. o.)

MARSHALL, D. [1984]: Adam Smith and the Theatricality of Moral Sentiments. Critical Inquiry, Vol. 10. No. 4. 592-613. o. http://dx.doi.org/10.1086/448266.

MCCloskey, D. [2002]: The Secret Sins of Economics., Prickly Paradigm Press, LLC. Chicago.

McCloskey, D. [2016]: Adam Smith Did Humanomics: So Should We. Előadás az Adam Smith at 240: Contemporary Views of Smith's Enduring Presence címü konferencián. Eastern Economic Association meetings. International Adam Smith Society, február 25. http://www.deirdremccloskey.com/docs/pdf/SmithDidHumanomics.pdf.

McCullough, M. E. [2008]: Beyond Revenge, The Evolution of the Forgiveness Instinct. Jossey-Bass, San Francisco, CA, 320 o.

MOKYR, J. [2005]: The Intellectual Origins of Modern Economic Growth. The Journal of $\begin{array}{lllllll}\text { Economic } & \text { History, } & \text { Vol. } & 65 . & \text { No. } & 285-351 . & \text { o. }\end{array}$ http://dx.doi.org/10.1017/s0022050705000112.

Mossner, E. C.-Ross, I. S. (szerk.) [1977]: The Correspondence of Adam Smith. Oxford University Press, Oxford. 
Mueller, P. [2015]: Adam Smith's Ethics: The Ethics of a Free Society. Augusztus 18. Libertarianism.org. http://www.libertarianism.org/columns/adam-smiths-ethics-ethicsfree-society.

NisbeTt, R. E. - CohEn, D. [1996]: Culture of Honor. The Psychology of Violence in the South. Westview Press. Oxford. 119 o.

OVERY, K.-MOLNAR-SZAKACS, I. [2009]: Being Together in Time: Musical Experience and the Mirror Neuron System. Music Perception, Vol. 26. No. 5. 489-504. o. http://dx.doi.org/10.1525/mp.2009.26.5.489.

Paganelli, M. P. [2010]: The moralizing role of distance in Adam Smith: The theory of moral sentiments as possible praise of commerce. History of Political Economy, Vol. 42. No. 3 . 425-441. o. http://dx.doi.org/10.1215/00182702-2010-019.

Paganelli, M. P. [2015]: Recent engagements with Adam Smith and the Scottish Enlightenment. History of Political Economy, Vol. 47. No. 3. 363-394. o. http://dx.doi.org/10.1215/00182702-3153104.

PINKER, S. (2011). 2011. Decline of violence: taming the devil within us. Nature 478(7369): 309-311. doi:10.1038/478309a

PhILliPson, N. [2010]: Adam Smith. An Enlightened Life. Yale University Press, New HavenLondon, $352 \mathrm{O}$.

PUTMAN, R. D. [1992]: Making Democracy Work. Civic Tradition in Modern Italy, University Press, Princeton, Princeton, New Jersey.

RAE, J. [1895/1965]: The Life of Adam Smith. Macmillan, London-New York, http://www.econlib.org/library/YPDBooks/Rae/raeLS.html.

RAPHAEL, D. D.-MACFIE, A. [1976]: Introduction to Adam Smith: The Theory of Moral Sentinents. Oxford University Press, London.

Russ, R. [2014]: How Adam Smith Can Change Your Life: An Unexpected Guide to Human Nature and Happiness. Penguin Books.

SEN, A. [2010]: Adam Smith and the contemporary world. Erasmus Journal for Philosophy and Economics, Vol. 3. No. 1. 50-67. o. http://ejpe.org/pdf/3-1-art-3.pdf.

SMITH, A. [1959]: A Nemzetek Gazdagsága. E gazdagság természetének és okainak vizsgálata. Fordította: Bilek Rudolf. Akadémiai kiadó, Budapest. 413. oldal.

SMITH, A. [1759/1977]: Az erkölcsi érzelmek elmélete. Megjelent: Márkus György (szerk.):_Brit moralisták a XVII. században. Fordította: Fehér Ferenc, Gondolat Kiadó, Budapest, 423553. 0.

Smith, A. [1983]: Lectures on Rhetoric and Belles Lettres. Szerk.: J. C. Bryce. Oxford University Press, Oxford.

SunD, E. M. K. A. [2010]: Literature and the Moral Imagination: Smithean Sympathy and the Construction of Experience through Readership. Thesis, Georgia State University, http://scholarworks.gsu.edu/philosophy theses/61.

ThaleR, R. H-Sunstein, C. R. [2009]: Nudge: Improving Decisions About Health, Wealth, and Happiness. Revised and Expanded edition, Penguin Books, New York stb.

WEINER, E. [2016a]: The Geography of Genius: A Search for the World's Most Creative Places, from Ancient Athens to Silicon Valley. Simon \&Schuster, New York, 368 o.

WEINER, E. [2016b]: The Secret of Immigrant Genius. Having your world turned upside down sparks creative thinking. Wall Street Journal, Eastern edition. január 16. 
Wight, J. B. [2006]: Adam Smith's Ethics and the "Noble Arts". Review of Social Economy, Vol. 64. No. 2. 155-180. o. http://dx.doi.org/10.1080/00346760600721114.

Wilson, E. O. [2012]: The Social Conquest of Earth. Liveright Publishing, New York.

Young, J. T. [1997]: Economics As a Moral Science: The Political Economy of Adam Smith. Edward Elgar, Cheltenham, 225 o.

Young, J. T. [2013]: A Review of Some Recent Smith Scholarship. Oeconomica, 1. 147-164. o. http://dx.doi.org/10.4074/S2113520713011079.

ZAK, P. J. (szerk.) [2008]: Moral Markets: The Critical Role of Values in the Economy. Princeton University Press, Princeton, 3920. 